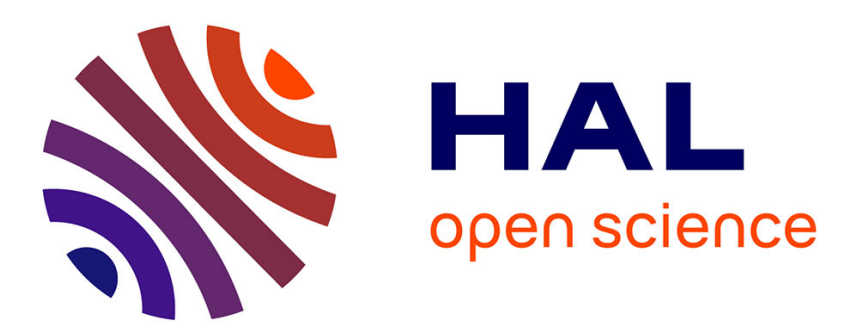

\title{
Outer-suburban politics and the financialisation of the logistics real estate industry: The emergence of financialised coalitions in the Paris region
}

\author{
Nicolas Raimbault
}

\section{- To cite this version:}

Nicolas Raimbault. Outer-suburban politics and the financialisation of the logistics real estate industry: The emergence of financialised coalitions in the Paris region. Urban Studies, 2021, pp.004209802110144. 10.1177/00420980211014452 . hal-03506837

\section{HAL Id: hal-03506837 https://hal.science/hal-03506837}

Submitted on 2 Jan 2022

HAL is a multi-disciplinary open access archive for the deposit and dissemination of scientific research documents, whether they are published or not. The documents may come from teaching and research institutions in France or abroad, or from public or private research centers.
L'archive ouverte pluridisciplinaire HAL, est destinée au dépôt et à la diffusion de documents scientifiques de niveau recherche, publiés ou non, émanant des établissements d'enseignement et de recherche français ou étrangers, des laboratoires publics ou privés. 


\section{Outer-suburban Politics and the Financialization of the Logistics Real}

\section{Estate Industry. The Emergence of Financialized Coalitions in the}

\section{Paris Region}

Nicolas Raimbault

University of Nantes, Institute of Geography and Regional Planning, CNRS UMR 6590

"Espaces et SOciétés” (ESO), France

Preprint version of:

Raimbault, N. (2021). Outer-suburban politics and the financialisation of the logistics real estate industry: The emergence of financialised coalitions in the Paris region. Urban Studies, 00420980211014452. https://doi.org/10.1177/00420980211014452

\section{Acknowledgements}

An earlier version of this work has been presented at the AAG 2018 Conference, during the special session "Real Estate, Finance and Urban Development" organized by Manuel Aalbers (New Orleans, April 2018). I wish to thank Ludovic Halbert for his precious help and insightful comments. The usual disclaimers apply.

\section{Introduction}

Logistics activities have been developing since the 1970s and as such, large logistics zones grouping warehouses have multiplied in outer suburban regions. This dynamic 
has led to the emergence of a specialized logistics real estate industry within the commercial real estate industry (Hesse, 2008). In most advanced economies, the same global specialized real estate investment funds dominate this real estate market by simultaneously acting as developers, investors, and fund managers (Raimbault, 2016). This dynamic is indicative of the current financialization of the logistics real estate market, but it is in contrast with other real estate markets. On the one hand, financialization of the commercial and residential property markets is leading to more integration between the production of the built environment and international financial markets (Halbert and Attuyer, 2016), and on the other, it is a dynamic that is compatible with the permanence of domestic financial agents (Wijburg and Aalbers, 2017), and even more so, with domestic property developers who organize and negotiate the 'anchoring' of capital in specific national, regional and urban contexts (Theurillat and Crevoisier, 2014). In other words, through its greater global reach and integration, the logistics real estate industry is moving along its own unique financialization path.

Nevertheless, the literature on global logistics urbanization does not specifically address the processes involved in the financialization of logistics properties to explain the current spatial dynamics (e.g.: Hesse, 2008; Cowen, 2014). Similarly, the literature on the financialization of urban production (e.g.: Halbert and Attuyer, 2016) does not deal with the specific case of logistics.

In light of this double-blind spot, the present paper aims to explain the specific features of the financialization of the logistics real estate industry, that is, its greater internationalization and integration due to the emergence of global players. Why is this industry's business model - the global integration of fund management on the one hand, and real estate and land development on the other - the dominant model worldwide? 
What effects does this financialization have on the way in which logistics spaces are currently produced? These empirical questions raise the issue of the transformation of local governance through financialization processes. Elaborating on the financialized production of logistics zones, the paper provides a more in-depth understanding of the power relations between local authorities and financial investors, and of the coalitions they build (Guironnet, 2017). It highlights the importance of distinguishing between different types of real estate (residential, commercial and logistics) and between different types of urban spaces (cities, inner and outer suburbs - see: Phelps, 2017) to understand the particular effects of financialization on local governance.

To address these issues, the paper combines an analysis of the financial circuits relating to the logistics built environment with a study of local public-private coalitions, and of the subsequent emerging power relations required to develop logistics zones. It examines the dynamics of European and French logistics real estate markets, and also presents two case studies of logistics zones in the Paris Region, an emblematic area of the rise of continental logistics metropolises (Dablanc and Frémont, 2013). In a domain marked by case studies set in North America and on dense urban spaces, the present paper provides a European and outer-suburban perspective on the financialization of urban production. It shows that the dominance of integrated, and often global, companies and strategies in logistics real estate relies in particular on their capacity to locally negotiate the development of private logistics zones, which involves the capacity to form local coalitions (Logan and Molotch, 1987).

The first section of the paper presents the theoretical framework and the methodological approach adopted; the second studies the specific dynamic of the financialization of the logistics real estate market in France and Europe; and the third explains this dynamic 
through an analysis of the local public-private coalitions created to produce logistics zones in outer-suburban areas.

\section{Logistics urbanization and the financialization of urban production: sociotechnical mediations and local coalitions}

Logistics urbanization studies highlight how the production of logistics spaces has contributed to urban sprawl and the role of local governance mechanisms in these spatial dynamics (section 1.1). To accurately analyse the role of financial investors in the production of logistics zones in outer-suburban areas, the paper combines two approaches: sociotechnical mediation to reveal the complex logic of the actors involved, and urban regime theory to examine the activities of financial investors in local governance and growth coalitions. The two approaches are complementary as a sociotechnical mediation analysis highlights the key role played by public-private coalitions, and concepts from the field of urban political economy effectively enable an understanding of this aspect of the financialization processes. Furthermore, both approaches are particularly relevant in the outer-suburban context (section 1.2). In accordance with this, a two-fold qualitative methodology is adopted (section 1.3).

\subsection{Logistics urbanization: urban sprawl and outer-suburban politics}

With the advent of globalization, the increasing complexity of production and distribution networks, and more recently the upsurge in e-commerce, logistics activities have undergone significant development since the 1970s, which has manifested in large 
logistics zones concentrating warehouses in the outer suburbia of urban regions (Hesse, 2008; Cidell, 2015).

Research in several European and North American city regions presents a process of 'logistics sprawl', which is defined as the relocation of logistics facilities away from inner urban areas to outer-suburban areas (Cidell, 2010; Dablanc and Ross, 2012). The case of logistics confirms how important the relocation of economic activities is in our understanding of suburban and exurban growth (Phelps, 2017). Logistics sprawl is explained by the specific spatial requirements of the logistics industry (Strale, 2020) and by the specific urban governance arrangements supporting logistics growth (Dablanc and Ross, 2012). These studies highlight the lack of regional coordination and, therefore, the primary role played by municipalities and local communities in the regulation of logistics land use (Cidell, 2011), which contributes to urban sprawl (Barbier et al., 2019). Some authors also point to the increasing power of the logistics real estate industry in terms of selection of logistics locations and definition of the features of logistics buildings (Hesse, 2008; Cidell, 2011).

In this way, logistics urbanization occurs in the specific configuration of outer-suburban politics, possibly according to dynamics other than residential suburbs or retail and office development of post-suburbia (Phelps and Wood, 2011). Indeed, the precise role of the financialization of logistics properties in local governance still needs further study.

1.2. Theoretical framework: financialization processes and outer-suburban governance 


\subsubsection{Sociotechnical mediations of the financialization of urban production}

For more than a decade, authors in the urban studies field have dissected the relationship between real estate, urban development and financial markets (e.g.: Aalbers, 2018, 2019). They highlight that the financialization of urban production corresponds to the current growing importance of financial markets, investors and intermediaries (practices and processes) in the development and management of the urban built environment.

More precisely, these institutionalist approaches investigate the interventions of financial intermediaries in urban production processes, and their interactions with the other (public and private) actors involved in these processes. These financial circuits are conceptualized as sociotechnical mediations 'that channel investments in the forms of equity and debt into urban production' (Halbert and Attuyer, 2016: 1347). They correspond to technical mediations as investment decisions are based on standardized investment practices resulting from the circulation of ideas, business models, and technologies between the financial intermediaries. They also correspond to social mediations as finance capital is gradually introduced into the urban built environment depending on the interactions, power relations and local coalitions between private and public actors (on this concept, see: Halbert and Attuyer, 2016). Their actions and interactions anchor the financial capital in specific built forms and places.

Analysis of the interactions resulting from the sociotechnical mediations between financial investors, intermediaries and other actors involved in city-making indicates that the power relations are strongly asymmetric, favouring the dominance of the 
investment and real estate industry over urban development projects. Developers, that are generally domestic or even regional, align their products with investors' standards (Guironnet et al., 2016). Local authorities have legal and financial resources that can be bargained for or that can influence built forms and spaces. However, negotiations concerning urban development projects are strongly framed by the investment standards of the financial intermediaries, i.e. the interests of the end-buyers of the properties. Eventually, financial re-intermediation heightens socio-spatial inequalities and challenges the ability of local governments to engage in long-term urban policies. Property investors select the tenants (Henneberry and Mouzakis, 2014), and thus directly challenge any political attempt to plan a diversity of economic activities within an urban project. These last aspects highlight the impact of the intervention of financial intermediaries on the restructuring of urban governance practices.

Accordingly, this perspective on urban governance from the analysis of the financial circuits echoes the call for research into the "processes of financialization from the perspective of city governments' (Weber, 2010: 256). Weber shows that local governments can be active agents of financialization processes, even by manufacturing investment instruments and asset classes (Weber, 2010). However, the precise interactions (negotiations, tensions and conflicts) between financial intermediaries, real estate and land developers, and local governments within urban development projects as well as their impact in terms of socio-spatial configurations and urban governance arrangements - are still under-investigated. In this perspective, Guironnet shows that urban development projects must be understood as the results of 'power relations between a city government with its own multiple objectives, and the expectations of financial investors about what cities should be' (Guironnet et al., 2016: 1459). In this 
way, financial re-intermediation in urban production could lead to the emergence of specific public-private coalitions, conceptualized as 'financialized growth coalitions', composed of the urban government, private developers and real estate advisors, and aimed at maximizing economic value for investors, even in the case of municipalities that are not obviously engaged in urban entrepreneurialism (Guironnet, 2017: 514).

Existing literature on the financialization of urban production emphasizes the importance of disentangling the financial circuits involved in the production of logistics zones to understand the role of investors and property fund managers in urban production. This involves analysing the business models, investment standards and practices of the logistics real estate industry (section 2). Moreover, research focused on sociotechnical mediations also underlines the importance of local governments, forming coalitions and manufacturing investment instruments. This means that the theoretical framework needs to include concepts about interactions and coalitions between investment and property industries and local authorities, and the impact on local policies. Analysing such local coalitions involves a discussion on urban power theories from the perspective of the financialization of urban production. Urban regime theory is an approach enabling such coalitions to be analysed, and is relevant in the suburban context (Phelps and Wood, 2011).

\subsubsection{Urban regime theory in the context of the financialization of outer-suburban production}

The urban political economy addresses the issue of public-private coalitions through two main concepts: Urban Regime Theory (URT) (Stone, 1989, 1993) and Growth 
Coalitions (GC) (Logan and Molotch, 1987). URT is based on the idea that urban policies are produced and implemented by informal, but stable, coalitions of governmental and non-governmental actors. Public and private actors with diverse interests bring their resources into the coalition to build a 'capacity to govern', which is often - but not necessarily - aimed at increasing urban growth: the 'development regimes' (Stone, 1993). Thus, URT echoes the concept of GC (Logan and Molotch, 1987).

Logan and Molotch show that local firms and institutions form informal coalitions with local governments to maximize urban growth. The authors highlight the central role played by local real estate entrepreneurs in the implementation of pro-growth urban policies. Within the concept of GC, Logan discusses the impacts of the globalization of capital flows, financial services and real estate industry on local politics and concludes that 'the local dimension is not bypassed but incorporated into larger networks. (...) The parochial participants in the city growth machine $(\ldots)$ continue to have a critical role' (Logan, 1993, p. 48). In 2004, Wood confirms this enduring parochialism in relation to the local scale of knowledge, social networks and political affairs. Institutionalist perspectives of financialization have the potential to update and set out this issue that still needs to be resolved.

URT is a conceptual approach used to analyse, within urban governance arrangements, the dynamics and the horizontal interactions between the actors, groups and organizations in coalitions, and to understand the capacity to govern and the 'power to' implement urban development projects, which these coalitions can, or cannot, build (Pinson, 2010). URT is an effective approach for investigating the specific interventions of financial intermediaries and investors in the construction of common policy agendas, 
as well as their coalitions with local authorities and other actors in urban production that work on implementing these agendas. It reveals the resources that are exchanged, the cooperation regimes between the different actors, and their respective benefits.

GC and URT provide a relevant theoretical framework for studying suburban politics (Phelps and Wood, 2011). In this paper, it is argued that URT allows a comprehensive understanding of the outer-suburban coalitions related to the financialization of the logistics real estate. As with every similar urban project, the development of logistics zones is necessarily embedded in a diversity of public actions implemented by the (small) municipalities of outer-suburbia: business zone developments, building permits and small transport facilities. On the one hand, such development projects require the construction of public-private coalitions. On the other hand, outer-suburbia concentrates many political and systemic economic dynamics, presented as the conditions for the emergence of development regimes (Stone, 1993) or growth coalitions (Logan and Molotch, 1987). These local governments have a high level of local autonomy, but low levels of technical, financial and administrative public capacities, coupled with the low influence of politics and political parties in local policies (Charmes, 2011). Furthermore, as logistics zones tend to be the only economic activities in these places, fiscally speaking, local governments are more heavily dependent on these projects.

Therefore, this paper combines the study of outer-suburban coalitions with the study of the sociotechnical mediations of the financialization of logistics real estate.

\subsection{Methodological approach}


Focusing on the European logistics real estate market and on the outer suburbs of Paris, the paper contributes to the comparative analysis of the financialization of urban production through a two-fold qualitative methodology (on comparative urbanism, see Robinson, 2014).

First, in a field dominated by North American studies, the paper examines the financial circuits and investment standards of logistics real estate by analysing the European and French logistics development and property markets. The investigations comprise the study of corporate documents, trade newspaper articles, business magazines and brokers' market analyses, and 19 semi-structured interviews conducted with the main international and national investors, fund managers, and logistics real estate developers based in Paris and the Netherlands.

Second, it provides an exhaustive analysis of the production processes of two logistics zones in the outer suburbs of Paris. Comparative case studies provide an appropriate methodology for analysing the process of financialization of logistics spaces, through the same analytical framework (power relations between the actors through the analysis of sociotechnical mediations and local coalitions), in two different local contexts $-\mathrm{a}$ productive means (MacFarlane and Robinson, 2012) for understanding both the structural logics of financialization and the possibly variegated local political mechanisms and spatial outcomes. To contrast two spatial and institutional outersuburban configurations, the logistics clusters of Val Bréon and Sénart in the Paris region (Figure 1) are studied. Val Bréon and Sénart are both located on the fringes of the Parisian urban agglomeration. While Val Bréon corresponds to the concentration of 
small villages progressively caught up in urbanization, Sénart is a new town planned and developed by specific State institutions. ${ }^{1}$

Figure 1. Case studies in the Parisian logistics landscape.

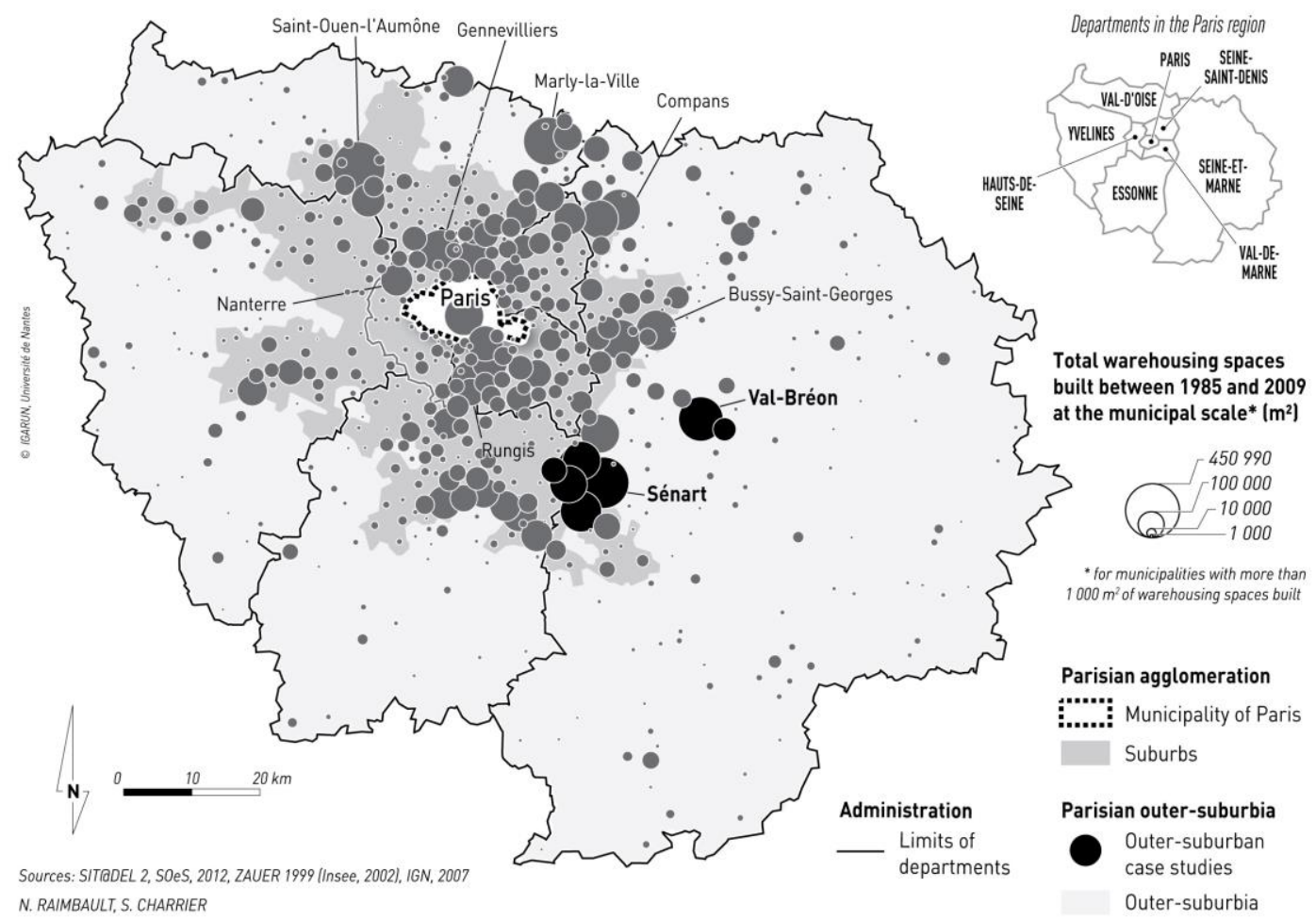

The case studies comprise 17 semi-structured interviews with members of local authorities and employees of semi-government land development companies ( 3 in Val Bréon, 10 in Sénart, and 4 regional actors), and an analysis of planning and public policy documents from these local institutions. The scope of the interviews is similar to other logistics zone case studies conducted in the metropolitan areas of Chicago (Cidell, 2011), Atlanta (Dablanc and Ross, 2012), San Francisco and Berlin (Hesse, 2008), or

\footnotetext{
${ }^{1}$ New towns were an initiative created by the French government in the 1970s to regulate the urbanization of the Paris region.
} 
Frankfurt and Kassel (Barbier et al, 2019). The interviews covered all stakeholders involved in the production of the two spaces.

The following sections explain the practices of the financial intermediaries and investors, and the interactions within local coalitions during the design, development and management of logistics zones. They address the business models, the investment standards of this real estate industry, and their circulation (section 2), as well as the engagement of the real estate logistics industry with local politics (section 3).

\section{Financialization of the logistics real estate industry: globalization and integration of the production of logistics parks}

The development of the logistics industry since the 1970s has led to the emergence of a recent but fast-changing logistics real estate industry (Hesse, 2008), which has become increasingly distinct from other real estate business. This section presents the demand and supply side of these dynamics, thereby showing this industry's investment standards and practices.

\subsection{Towards flexible logistics spaces}

The emergence of a logistics real estate market is relatively recent (Mattarocci and Pekdemir, 2017). Before the 1990s, most warehouse users - manufacturing firms and retailers running their own logistics activities (the shippers) or logistics services providers - constructed their own buildings (Hesse, 2008). 
From the 1990s, shippers and logistics services providers have tended to opt for 'flexible' real estate solutions such as renting rather than owning warehousing facilities. This is, moreover, reinforced by a specific logic of spatial flexibility inherent in the current organization of logistics networks. The optimization of logistics networks is mainly achieved by changing the number of warehouses (network nodes), their size and their localization. Renting warehousing spaces therefore provides the option of modifying the networks. To strengthen this flexibility, shippers not only outsource the management of warehousing spaces to logistics services providers, but also often decide to give the responsibility of renting the space to the same providers ${ }^{2}$, which in this context, relies heavily on the availability of short-term leases. ${ }^{3}$

The evolution of the demand for logistics space has contributed to the emergence of a logistics real estate development market, and, moreover, an investment market. Their role involves being able to supply such flexible logistics spaces in attractive and cheap locations, i.e. in the (outer) suburbs of the main urban areas which are the largest logistics markets (Kang, 2020).

These market features assume that real estate investors will eventually manage an important portfolio of properties anticipating the demand of the logistics companies, with some vacancies for new leases. If there are no warehouses available in the approximate area selected by the logistics firms, this real estate industry must be able to respond by quickly building new ones. This second solution is only possible if investors already own plots of land, which must be prepared and authorized for development, and have obtained the necessary administrative permits. Accordingly, these market features

\footnotetext{
${ }^{2}$ Interview with Carrefour Supply Chain Management Director, 16 November 2011.

${ }^{3}$ Interview with DHL France Real Estate Director, 13 February 2013.
} 
favour not only the emergence of a logistics property market, but also the specific financialization of logistics real estate leading to the emergence of integrated and specialized global firms.

\subsection{Financialization, integration and globalization}

Logistics facilities are attractive financial assets for most investors. In order to propose logistics assets to financial markets, several financial intermediaries manage investment funds that own warehouses for rent (table 1). The study of companies active in the logistics real estate development and investment markets in France and Europe (Hesse, 2008) identifies two financialized investment circuits that are based on different organizational and institutional arrangements, but which converge towards similar investment standards.

Table 1. Main logistics fund managers in $\mathbf{2 0 2 0}$

\begin{tabular}{|c|c|c|c|}
\hline Companies & Nationality & Activities & Properties under management (USD $-\mathrm{m}^{2}$ ) \\
\hline Prologis & $\begin{array}{l}\text { United- } \\
\text { States }\end{array}$ & $\begin{array}{l}\text { Land and real estate } \\
\text { developer - investment } \\
\text { fund manager }\end{array}$ & $\begin{array}{l}148,3 \text { billion }-49,3 \text { million ( } 3,401 \text { buildings in } \\
17 \text { countries and } 10 \text { investment funds) }\end{array}$ \\
\hline $\begin{array}{l}\text { Global Logistics Properties } \\
\text { (GLP) }\end{array}$ & Singapore & $\begin{array}{l}\text { Land and real estate } \\
\text { developer - investment } \\
\text { fund manager }\end{array}$ & $\begin{array}{l}59 \text { billion - } 66 \text { million ( } 2,500 \text { properties in } 17 \\
\text { countries and } 23 \text { investment funds) }\end{array}$ \\
\hline Goodman & Australia & $\begin{array}{l}\text { Land and real estate } \\
\text { developer - investment } \\
\text { fund manager }\end{array}$ & $\begin{array}{l}51.8 \text { billion - } 19.3 \text { million (392 properties in } \\
17 \text { countries) }\end{array}$ \\
\hline Segro & $\begin{array}{l}\text { United } \\
\text { Kingdom }\end{array}$ & $\begin{array}{l}\text { Land and real estate } \\
\text { developer - investment } \\
\text { fund manager }\end{array}$ & $\begin{array}{l}21.1 \text { billion ( } \mathrm{f} 15.3 \text { billion) }-8.8 \text { million ( } 8 \\
\text { European countries) }\end{array}$ \\
\hline $\begin{array}{l}\text { Logicor investment fund } \\
\text { (China Investment } \\
\text { Corporation) }\end{array}$ & China & Investment fund manager & $\begin{array}{l}15.6 \text { billion ( } € 13.3 \text { billion) - } 13.6 \text { million (606 } \\
\text { properties in } 17 \text { European countries) }\end{array}$ \\
\hline
\end{tabular}




\begin{tabular}{|c|c|c|c|}
\hline $\begin{array}{l}\text { P3 (GIC: Singapore's } \\
\text { sovereign wealth fund) }\end{array}$ & Singapore & $\begin{array}{l}\text { Land and real estate } \\
\text { developer - investment } \\
\text { fund manager }\end{array}$ & $\begin{array}{l}\text { Unknown }-6.5 \text { million ( } 270 \text { properties in } 12 \\
\text { European countries) }\end{array}$ \\
\hline AEW & France & Investment fund manager & $\begin{array}{l}6.7 \text { billion ( } € 5.9 \text { billion) }-1.6 \text { million [in } 2019 \\
2020 \text { author own calculations] }\end{array}$ \\
\hline WDP & Belgium & $\begin{array}{l}\text { Land and real estate } \\
\text { developer - investment } \\
\text { fund manager }\end{array}$ & $\begin{array}{l}5.6 \text { billion ( } € 4.8 \text { billion) - more than } 4.5 \\
\text { million ( } 6 \text { European countries) }\end{array}$ \\
\hline Argan & France & $\begin{array}{l}\text { Real estate developer - } \\
\text { investment fund manager }\end{array}$ & $\begin{array}{l}3.5 \text { billion ( } € 3 \text { billion) - more than } 3 \text { million } \\
\text { ( } 87 \text { buildings in France) }\end{array}$ \\
\hline Logistics Capital Partners & UK & $\begin{array}{l}\text { Real estate developer - } \\
\text { investment fund manager }\end{array}$ & $\begin{array}{l}1.1 \text { billion ( } € 0.9 \text { billion - } € 1.5 \text { billion under } \\
\text { development) }-0.9 \text { million } \mathrm{m}^{2} \text { ( } 1.1 \text { million } \mathrm{m}^{2} \\
\text { under development) }\end{array}$ \\
\hline
\end{tabular}

Sources: La lettre de la pierre, 2013, 2018; websites and 2020 annual or financial reports.

On the one hand, the major non-specialized financial intermediaries, such as Blackstone and GE Real Estate (US), Axa IM and AEW (France), and Deka (Germany), manage investment funds that own logistics property. For instance, in 2012, Blackstone founded a logistics investment fund called Logicor (now owned by the Chinese sovereign wealth fund China Investment Corporation) which includes 606 properties (comprising 13.6 million $\mathrm{m}^{2}$ ) in 17 European countries. The constitution of the logistics properties relies mainly on domestic developers that build the warehouses according to the investment strategies and negotiate with local authorities and land developers. In this circuit, investment fund managers and real estate developers are separated.

On the other hand, the main logistics real estate investment funds, which clearly dominate the markets in France and worldwide and attract international flows of finance capital, are founded and managed by speciality Real Estate Investment Trusts (REITs). Prologis (United States), Global Logistic Properties (GLP, Singapore), Goodman (Australia) and Segro (United Kingdom) implement global investment strategies on logistics spaces. Moreover, these companies not only control the financial 
intermediations and investments, but also directly develop warehouses, which they acquire through one of their investment funds. In addition, they tend to be land developers: they usually directly develop logistics zones composed of several warehouses. This specialized, integrated and globalized way to produce logistics assets represents the dominant logistics real estate investment circuit. This circuit contrasts with the other logistics real estate investment circuit (presented above), which is more fragmented and separates financial agents and developers.

The dominance of the integrated circuit leads to two very connected dynamics: first, the globalization of the investment flows occurs along with the globalization of logistics zones' development practices. Second, financial re-intermediation materializes as the integration of all the real estate processes, from land and real estate development to the management of investment funds and the investments themselves. This globalization is explained by the modalities of the production of logistics spaces.

Understanding the dominance of the integrated circuit over the fragmented circuit and its effects requires a detailed study of the logistics zones they produce and thus their investment standards.

\subsection{Producing logistics parks at the global scale}

The main goal of the fund managers of the two investment circuits is to accumulate suitable property assets at the global scale so they can supply real estate solutions to similarly global logistics firms. However, in order to assemble these assets, investors and fund managers depend on the activity of developers. 
Within the fragmented investment circuit (presented above), to stimulate the production of logistics spaces by developers, some investors engage in close partnerships with selected partners. For instance, this is AEW's strategy, which has been expanding its LOGISTIS fund since 1999, mainly in collaboration with PRD, a French developer specializing in warehouses. In this way, these financial intermediaries largely determine the socio-technical mediations: developers align with investors' standards as in most urban redevelopment projects (Guironnet et al., 2016).

However, as the logistics real estate market is still relatively new, domestic and small developers are not able to provide the numerous expected logistics spaces. In this context, specialized logistics investment fund managers (integrated investment circuit) have decided to engage in development. Indeed, their capacity to accumulate large amounts of capital in their funds offers them the important capacity first to constitute large land banks, and then to build the warehouses they plan to buy.

Nevertheless, warehouse development is highly dependent on access to large plots of land, which must be located close to main cities and to major road infrastructure. This access is the main condition for the quantity, quality and pace of real estate development. In France, as well as in most other European countries, land is controlled by local governments in two ways: first, any real estate development must respect the municipal spatial planning regulations and projects require a building permit, and second, (inter)municipalities have traditionally themselves, or through local public land developers, developed business zones and sold the plots of land to private real estate developers. Consequently, the number of warehouses that investors can rent and develop (or have developed) is directly determined by local planning policies on business parks. The municipalities of the major agglomerations are not usually very 
enthusiastic about the development of new logistics zones as it does not translate into many jobs/taxes compared to the amount of land consumption. On the contrary, the ratios of jobs and taxes on land consumption are attractive for most outer suburban municipalities - excluding the richest ones (Strale, 2020). However, these municipalities lack the financial and technical capacities to develop logistics zones, especially as warehouses are becoming increasingly larger (up to or more than 150,000 $\mathrm{m}^{2}$ ) which calls for very large logistics zones (100 hectares or over).

To lessen their dependence on negotiations with local public authorities, two strategies are implemented according to financial circuit. In the fragmented circuit, some investors, with land and property developers, build joint ventures dedicated to a logistics zone project. In the integrated circuit, the main specialized fund managers (Prologis, Goodman, GLP and Segro) tend to be the land developers of the logistics zones in which they invest. In other words, instead of building warehouses scattered around different business zones, the integrated companies and some actors of the fragmented circuit tend to develop private logistics zones containing multiple warehouses. These logistics parks are entirely owned and operated by the same investment fund manager responsible for property management, directly or through a joint venture. They are fenced and protected by private security.

The concept of outer-suburban logistics parks that are directly connected to a major highway, subsumes the investment standard in the integrated circuit. In this way, companies secure land for logistics by controlling the entire process of the production and management of logistics parks over the long term, and by integrating land and real estate development and investment activities on a global scale. In order to compete with the major logistics real estate investors, the logistics park has also become the standard 
for investors in the fragmented circuit, which materializes in empowered domestic developers through partnerships with fund managers (see section 3.2).

Moreover, this privatization also secures logistics spaces within the local political context. Private ownership of a zone isolates it from most of the policy decisions that could constrain logistics activities or even progressively change the zone's authorized land use, as could happen in traditional business zones.

The emergence of a logistics real estate market dominated by investment fund managers eventually leads to a strong standardization of logistics zones and warehouses. These standardized logistics spaces meet the demands of the largest logistics firms. Nonetheless, small and medium-size enterprises looking for warehousing spaces are largely excluded from this market, which, for instance, does not provide logistics real estate solutions for companies looking for locations in dense urban spaces.

This business model also leads to the privatization of a number of local policies. Logistics real estate firms privatize land development policies as business zones were previously directly developed by municipalities, to the extent that logistics parks are entirely private: real estate firms become the de facto owners and managers of the streets and green spaces that constitute the public spaces in the business parks. Moreover, the model also enables real estate companies to decide on local economic development issues insofar as they select the companies that settle in the municipality, which considerably affects its economic specialization and prospects.

The production of logistics parks therefore implies that the local governments involved accept this privatization process. In this perspective, the success of integrated and often global real estate firms, whose business models imply intervention in local policies, is 
paradoxical when compared with other real estate markets. With the exception of logistics, global financial agents rely mainly on local actors for the anchoring of financial capital in urban spaces (Theurillat and Crevoisier, 2014). The dominance of the integrated circuit is explained by the capacity of these firms to control the development of private logistics zones. URT provides insight into both the political acceptance of the specific financialization of the logistics real estate market and its effect on local governance arrangements.

\section{Logistics outer-suburbanization: the emergence of financialized outer- suburban coalitions}

In order to analyse how logistics parks are authorized and supported by local governments, two case studies, corresponding to the two circuits and to two spatial and institutional configurations of the Paris region, are presented. This section shows two different political mechanisms that explain why local governments support this privatization (Raimbault, 2017). First, some outer-suburban local governments, due to a lack of financial, technical and even political resources, look for private investors to establish business zones. Second, other such municipalities see private logistics parks as a more efficient political tool to control local development policies compared to traditional, publicly developed business zones.

\subsection{Filling a political vacuum: the case of Val Bréon logistics park}

Val Bréon is an inter-municipal local authority about $50 \mathrm{~km}$ east of Paris $(15,000$ inhabitants in 10 municipalities). In one of the municipalities - Châtres, with 600 
inhabitants - a large, 200-hectare logistics park $\left(400,000 \mathrm{~m}^{2}\right.$ of warehousing space used today by logistics providers working for retailers and the luxury industry, and by parcel services; about 1,000 jobs) was developed between 2002 and 2009. The size of the development project, which represented an investment of $€ 300$ million, contrasted with the size of the municipalities involved and their limited capacities (Val Bréon total investment budget of $€ 192,000$ in 2009 , around $€ 1.3$ million annually since 2010 ).

The logistics zone was initially a public project launched in 1995 by the newly founded inter-municipal local authority, with the sole objective of attracting a few logistics companies to obtain financial resources to develop new public policies (transport, culture, nurseries, youth policy, etc.). However, the local authority lacked the administrative, technical and financial resources to develop the zone: 'It didn't want to implement it legally, financially. (...) It was out of the question to put a penny into it. So it was destined to become a completely private operation. (...) It had neither financial nor technical skills"4. 'The investor paid for everything, the roads, the buildings ... It cost the community $€ 1$ per inhabitant per year. ${ }^{5}$

As such, the local authority looked for a private land developer and investor to implement and finance the totality of this major project in its political agenda. It therefore welcomed the proposal of a joint venture between the developer PRD, and Amundi the real estate asset manager of leading French bank Crédit Agricole, to develop a private logistics park. The joint venture company - an example of the integration strategy of the fragmented financial circuit - was responsible for financing the entire operation, developing the site and buildings, finding companies to rent the

\footnotetext{
${ }^{4}$ Interview with the deputy director of PRD, 14 October 2011. All interview quotations have been translated from French by the author.

${ }^{5}$ Interview with the mayor of Châtres, 24 May 2011.
} 
warehouses, and the long-term management of the site. Apart from aesthetic aspects, and especially the design of the green spaces in the zone, the local government did not want any involvement in the operation. For instance, the selection of the companies using the warehouses was not considered a public issue and free rein was given to the developer-investor joint venture in this respect. In other words, the local government gave up some control over its territory in exchange for the private financing of the project. The fiscal revenues generated by the logistics zone now finance the authority's entire budget.

However, this example is more than the process of a land development concession. Indeed, the private firm was also tasked with the overall project management, including its political dimension. With regard to land development, the main challenge was to resolve a legal conflict with an environmental group that objected to the impact of the development project on local wetlands. The local authority asked the private land developer to negotiate with the group and to find a solution. ${ }^{6}$ The developer proposed selling the wetlands to the group for a symbolic price of one euro, which would protect the wetlands and involve the group in discussions on the design of the zone. The local authority also asked the company to extensively rewrite the local land use plan. 'The local land-use plan was co-produced with the investor, (...) They told us how to adapt the plan to the project. ${ }^{, 7}$ In this way, the real estate company undertook many of the activities that would usually have been carried out by local authorities under their urban and economic development policies.

\footnotetext{
${ }^{6}$ Interview with the President of the Val Bréon inter-municipal local authority, 15 October 2011.

${ }^{7}$ Interview with the mayor of Châtres, 24 May 2011.
} 
Eventually, the weakness of the public capacities and objectives of the local governments in the outer suburban areas largely explain the process of privatization as regards the development of logistics spaces. More precisely, privatization is the outcome of a need for private resources expressed by the local authority. In such a political context, i.e. in a political vacuum, the integration of land and real estate development and investment activities becomes possible. However, logistics parks have also been successfully developed in institutionally denser contexts.

\subsection{Private logistics park and institutional rivalry over the control of local development policies: the case of Sénart}

Sénart is a new town located $35 \mathrm{~km}$ southeast of Paris, and represents a very different institutional context to that of Val Bréon. As a new town, a public land developer (EPA Sénart) - who is accountable to central government and, unlike in Val Bréon, independent of municipalities - directly controls its development. Public policy capacities are thus important but are independent of local politics. Moreover, EPA Sénart has implemented a successful economic development strategy through attracting dozens of logistics firms. In the 1990s and 2000s, it designed a development programme for several logistics zones and for this purpose established strong links with domestic property developers that built warehousing space for rent on the different sites. In this way, Sénart became one of the main logistics centres in the Paris Region creating more than 7,000 jobs.

However, the new town municipalities have criticized the EPA Sénart monopoly over the development of logistics zones, as they feel excluded from the governance of the 
development of the new town. ${ }^{8}$ This context of conflict between EPA Sénart and the municipalities eventually enabled Prologis, the global leader in logistics real estate and the emblematic example of the integrated financial circuit, to develop its main logistics park in France: Prologis Chanteloup (200 hectares, with $250,000 \mathrm{~m}^{2}$ of warehouses used by parcel services, e-commerce, logistics providers, retailers, and the food industry).

In the early 2000s, Prologis bought a large agricultural plot in Moissy-Cramayel, one of the municipalities that are part of the Sénart new town. It immediately negotiated with the municipality about the possibility of building a logistics park as this required changes to the local land-use plan. Although the mayor initially rejected the project outright, there were three differences between the logistics park and the logistics zones developed by EPA Sénart that convinced him to change his mind. First, the general design of the park and the fact that it would be fenced and secure appeared to be an improvement on the EPA logistics zones. Second, as both the development and management aspects were entirely private, it made no demands on public funds. Third, the property manager, Prologis, would be solely responsible for the whole park and would deal directly with the mayor for any requests. This gave the mayor a greater sense of control over his territory compared with the EPA logistics zones. 'The private investors were totally dependent on the agreement of the municipal council, so they were attentive to our expectations. It's true that the EPA does not really need my goahead to develop. ${ }^{9}$ Indeed, the latter did not need the authorization from the mayor to develop a logistics zone, who subsequently, would not control the long-term management of the zones (since the plots would be owned by different investors). 'With

\footnotetext{
${ }^{8}$ Interview with the mayor of Combs-la-Ville, 9 September 2011.

${ }^{9}$ Interview with the mayor of Moissy-Cramayel and president of the Sénart inter-municipal organization, 17 June 2011.
} 
the mayor of Moissy it was about mutual trust. The President of Prologis Europe established a strong trusting relationship with the mayor.'10 'The project was coconstructed by the President of Prologis Europe and myself., ${ }^{11}$

In other words, the local government was fully convinced by the standard of the private logistics park compared with the logistics zones developed through the traditional public method of land development. On the one hand, this success echoes the notion of 'privatism': 'an underlying confidence in the capacity of the private sector to create the conditions for personal and community prosperity' (Barnekov et al., 1989: vii). On the other hand, the private project incapacitates the mayor vis-à-vis the state agency in a context of institutional tensions. In 2012, Prologis developed a new logistics park of the same size in the south of the municipality. Eventually, in this case, the privatization of the local land and economic development policies happened not directly because of the weakness of public policy capacities in the area, but most of all because of the limited scope of the municipal agenda. As soon as it sought more independency vis-à-vis EPA Sénart, the municipality focused only on logistics zone design and financial issues, at the expense of other issues such as environmental and social impacts. 'Chanteloup park today is a benchmark. I say that's what should be done in terms of development. (...) It's a good model for logistics. The idea of closed, private business parks - I think applies extremely well to logistics'.12

\subsection{Financialized growth coalitions in outer suburbia}

\footnotetext{
${ }^{10}$ Interview with Prologis southern Europe development director, 14 September 2011.

${ }^{11}$ Interview with the mayor of Moissy-Cramayel and president of the Sénart inter-municipal organization, 17 June 2011.

${ }^{12}$ Interview with the mayor of Moissy-Cramayel and president of the Sénart inter-municipal organization, 17 June 2011.
} 
The two case studies show that involvement by different logistics real estate companies led to the emergence of durable public-private coalitions between local governments, property developers and fund managers, in order to develop logistics parks. In both cases, the logistics firms themselves - the users of the warehouses - do not play a part. These coalitions are dedicated to the production and management of the parks and become involved before the users of the logistics facilities are known.

As the common goal is to locally stimulate logistics and property growth, these coalitions can be described as financialized logistics growth coalitions, understood as subcategories of the 'financialized growth coalitions' (Guironnet, 2017). A project may be public in origin (Val Bréon) or completely private (Sénart). However, in both cases, the real estate developers and fund managers are the dominant players in the coalitions. The purpose of the coalitions is to build at the local scale a capacity to govern for the development of logistics parks that is in line with the criteria of financial investors. This happens in two contexts: very weak local governments, and tense conflicts between state agencies and local mayors. This kind of coalition echoes the urban regimes concept and more precisely that of 'development regimes' (Stone, 1993). In outer suburbia, 'The weakness of formal authority leaves a vacuum [weak public policy capacities, narrow scope of municipal agendas] that business interests have the ready resources to fill' (Stone, 1993: 26). The powerful real estate actors that emerged in the context of the financialization of logistics properties had both the interests and the resources to fill this vacuum.

The financialization of producing logistics spaces in the outer suburban context therefore leads to the emergence of specific suburban regimes resulting from the requirements of the development of logistics parks. These regimes, dominated by 
logistics real estate companies, bring the capacity to develop huge parks in the outer suburbs, where there is usually a lack of public capacities to stimulate important economic development.

At the regional scale, the financialization of producing logistics zones directly challenges planning policies. As this type of real estate is particularly attractive for outer suburban areas - where local authorities do not have the resources or desire to develop logistics zones alone - the financialization of logistics real estate has greatly contributed to urban sprawl since the 1990s (Dablanc and Ross, 2012) and thus to the spatial mismatch between the workplace and the home faced by logistics workers (Cidell, 2011).

At the local scale, within these coalitions, local governments negotiate only with property developers and fund managers. They rarely meet the warehouse users, workers, unions or even the logistics companies themselves. Managing the relationships with the firms that rent the warehouses becomes the task of the property manager alone.

Logistics parks developers sometimes face environmental or neighbourhood oppositions. However, the social movements focus almost exclusively on land development issues, approaching them from an environmental or quality-of-life perspective. As a result, logistics zone issues are seen as a question of real estate management that are disconnected from matters relating to logistics services production and employment, such as working conditions, employee transport and sustainable freight transport.

\section{Conclusion}


The analysis of the sociotechnical mediations related to the financialization of logistics real estate shows that integrating the production and management of logistics spaces into international financial markets is performed through two financial circuits. The dominance of integrated companies acting as land/real estate developers and fund managers is what makes the financialization of logistics real estate unique. This integration enables these firms to produce logistics spaces ideally suited to the demands of logistics firms requiring flexible sites. At the same time, it assumes that these (global) companies establish coalitions with the local governments involved in the development of logistics parks. Urban regime theory reveals that these firms have powerful financial, technical and political resources, which give them crucial power in the political context of outer-suburban areas. Studying the local coalitions structured around the production of logistics parks is thus an efficient way to explain the financialization of the logistics spaces.

Moreover, this approach highlights the importance of distinguishing between cities and suburbs when studying the financialization processes and the subsequent public-private coalitions. This spatial distinction partially explains the specific financialization of logistics spaces and also identifies the following understudied effect of the financialization of urban production. The involvement of powerful investment funds in the outer suburban areas profoundly restructures urban governance through the privatization of economic and land development policies. The two cases in the present paper show the outcomes of weak public policy capacities and agendas in the Paris outer suburbs. These findings are contrary to the common viewpoint that urban planning policies are more stringent in Europe than in North America. 
The public-private coalitions required for the development of logistics parks clearly affect political agendas, and in this way, the urban geography and socio-spatial inequalities. The financialization of logistics real estate contributes to concentrating blue-collar jobs in privately managed activity zones, in these outer suburban places where workers generally do not live and are omitted from local policy and political agendas (De Lara, 2018). These results therefore call for more evidence on the financialization of residential, commercial and industrial (outer)suburban spaces, including their effects on workplace governance.

To assess the State's role in financialization processes (Aalbers, 2019), the present research recommends that the diversity and the variegation of State configurations in urban spaces and beyond are considered at the regional and international scales. This will entail linking the analysis of strong public agencies of financialization (Weber, 2010) with outer-suburban financialization mechanisms that are more directly initiated and driven by private companies.

\section{References}

Aalbers M (2018) Financial geography II: Financial geographies of housing and real estate. Progress in Human Geography 43(2), 376-387.

Aalbers M (2019). Financial geography III. Progress in Human Geography 44(3): 595607.

Barbier C, Cuny C and Raimbault N (2019) The production of logistics places in France and Germany: a comparison between Paris, Frankfurt-am-Main and Kassel. Work Organisation, Labour \& Globalisation 13(1), Spring 2019: 30-46.

Barnekov T, Boyle R and Rich D (1989) Privatism and Urban Policy in Britain and the United States. Oxford: Oxford University Press. 
Charmes E (2011) La ville émiettée: essai sur la clubbisation de la vie urbaine. Paris : Presses Universitaires de France.

Cidell J (2010) Concentration and decentralization: The new geography of freight distribution in US metropolitan areas. Journal of Transport Geography, 18(3), 363-371.

Cidell J (2011) Distribution centers among the rooftops: the global logistics network meets the suburban spatial imaginary, International Journal of Urban and Regional Research 35(4): 832-851.

Cidell J (2015) Distribution centers as distributed places. Birtchnell T., Savitzky S. and Urry J. (Eds.) (2015). Cargomobilities: moving materials in a global age. New York: Routledge, 17-34.

Cowen D (2014) The Deadly Life of Logistics: Mapping Violence in Global Trade. Minneapolis: University of Minnesota Press.

Dablanc L and Ross C (2012) Atlanta: A Mega Logistics Center in the Piedmont Atlantic Megaregion (PAM). Journal of Transport Geography 24: 432-442.

Dablanc L and Frémont A. (2013) The Paris region. Operating and planning freight at multiple scales in a European city. P.V. Hall and M. Hesse (eds.), Cities, Regions and Flows, Oxon: Routledge, 95-113.

De Lara JD (2018) Inland Shift: Race, Space, and Capital in Inland Southern California. Berkeley and Los Angeles: University of California Press.

Guironnet A, Attuyer K and Halbert L (2016) Building Cities on Financial Assets: The Financialisation of Property Markets and Its Implications for City Governments in the Paris City-Region. Urban Studies 53(7): 1442-1464.

Guironnet A (2017) La financiarisation du capitalisme urbain: Marchés immobiliers tertiaires et politiques de développement urbain dans le Grand Paris et le Grand Lyon, les projets des Docks de Saint-Ouen et du Carré de Soie. Doctoral dissertation, Paris Est.

Halbert L and Attuyer K (2016) Introduction: The financialisation of urban production: Conditions, mediations and transformations. Urban Studies 53(7): 1347-1361. 
Henneberry J and Mouzakis F (2014) Familiarity and the Determination of Yields for Regional Office Property Investments in the UK. Regional Studies 48(3): 530546.

Hesse M (2008) The City as a Terminal. The Urban Context of logistics and Freight Transport. Aldershot, Ashgate, 'Transport and mobility series'.

Logan J (1993) Cycles and trends in the globalization of real estate. Knox P. (ed) The restless urban landscape. Englewood Cliffs, N.J.: Prentice Hall, 35-54.

Logan J and Molotch H (1987) Urban Fortunes. The Political Economy of Place. Berkeley: University of California Press.

McFarlane C and Robinson J (2012) Introduction-experiments in comparative urbanism. Urban Geography, 33(6): 765-773.

Mattarocci, G., and Pekdemir, D. (2017) Logistic Real Estate Investment and REITs in Europe. Cham: Palgrave Macmillan, Springer.

Phelps NA (2017) Interplaces: An economic geography of the inter-urban and international economies. Oxford University Press.

Phelps NA and Wood AM (2011). The new post-suburban politics?. Urban Studies $48(12), 2591-2610$.

Pinson G (2010) La gouvernance des villes françaises. Du schéma centre-périphérie aux régimes urbains. Métropoles 7.

Raimbault N (2016) Ancrer le capital dans les flux logistiques: la financiarisation de l'immobilier logistique. Revue d'économie régionale et urbaine 1: 131-154.

Raimbault N (2017) Le développement logistique des grandes périphéries métropolitaines: régimes (péri)urbains et privatisation silencieuse de la production des espaces logistiques. Métropoles 21.

Robinson J. (2014) Introduction to a virtual issue on comparative urbanism. International Journal of Urban and Regional Research.

Strale M. (2020) Logistics sprawl in the Brussels metropolitan area: Toward a sociogeographic typology. Journal of Transport Geography 88: 102372. 
Stone C (1989) Regime Politics: Governing Atlanta 1946-1988. Lawrence: University Press of Kansas.

Stone C (1993) Urban Regimes and The Capacity to Govern: A Political Economy Approach. Journal of Urban Affairs 15(1): 1-28.

Theurillat $\mathrm{T}$ and Crevoisier O (2014) Sustainability and the anchoring of capital: Negotiations surrounding two major urban projects in Switzerland. Regional Studies 48(3): 501-515.

Weber R (2010) Selling City Futures: The Financialization of Urban Redevelopment Policy. Economic Geography 86(3): 251-274.

Wijburg G and Aalbers MB (2017) The internationalization of commercial real estate markets in France and Germany. Competition \& Change 21(4): 301-320.

Wood A (2004) The scalar transformation of the US commercial property-development industry: a cautionary note on the limits of globalization. Economic Geography, 80(2): 119-140.

Kang S (2020) Why do warehouses decentralize more in certain metropolitan areas?. Journal of Transport Geography 88: 102330. 